424p. $\$ 32.50$. LC 77-25282. ISBN 0-89232-007-9.

A Practical Approach to Serials Cataloging ostensibly aims to teach librarians how to catalog a serial, but for a number of reasons the text is not geared for instruction. The author has covered everything that might conceivably fall within the scope of serial cataloging and as a result has highlighted the problems without offering workable solutions. Through emphasis on coverage, organization and brevity have suffered. The future cataloger is not guided logically through the stages required to create a catalog entry, and the rambling text makes it difficult to extract the portions on the practical aspects of cataloging.

Of the eighteen chapters, only about eleven are concerned with the construction of a serial catalog entry. Basic cataloging tools and reference works essential to the cataloger are not mentioned in the opening portion of the text, nor is searching. Almost at once the reader is plunged into a discussion of serial entry, which focuses on rule six of the Anglo-American Cataloging Rules (AACR). When the discussion reaches $A A C R$ 6B1, the reader is not informed that only certain categories of material are covered by this rule, and that the exception accompanying the rule relates only to these categories.

The chapter on title changes discusses the pros and cons of earliest, latest, and successive entry cataloging without adequately identifying the major differences between the cataloging entries.

Large portions of chapter seven of AACR have been reproduced in the chapter on descriptive cataloging, but revised chapter six is rarely even cited. Yet rules from both of these chapters are followed when transcribing bibliographic data onto the catalog entry. Often the author claims the rules in chapter seven are obvious, but history has proved otherwise, for catalogers have been subjected to endless interpretations. Although she recommends practices and procedures that violate the $A A C R$ in this chapter and elsewhere in the text, she often does not make it clear that they are nonstandard.

Selection of the title page, which is crucial to accurate bibliographic description, is mentioned briefly on page 97 in the chapter on descriptive cataloging. The author dismisses the subject because the majority of serials do not have title pages. The majority of periodical issues are published without title pages, but not the majority of serials. And even if her observation were true, the cataloger still has to know how to select a title page or a title page substitute. This erroneous statement is one of many that are made, particularly when the author embarks upon a discussion of serial cataloging at the Library of Congress.

Unfortunately, the impact of automation on serials cataloging in the past couple of years has dated the book prior to publication. For example, cooperative on-line cataloging, a result of the CONSER Project, is not mentioned.

An unusual and admirable feature of the book is the emphasis on the relation between technical and public service. Although excellent indexes and useful lists accompany the text, there is no glossary of cataloging and bibliographic terms. In fact, the author gives little attention to defining the library terms she uses.

Regretfully, for all of the above reasons, the text fails in its main purpose, to teach the basic principles of serial cataloging.Judith P. Cannan, Washington, D.C.

ABSTRACTS

The following abstracts are based on those prepared by the ERIC Clearinghouse on Information Resources, School of Education, Syracuse University.

Documents with an ED number here may be ordered in either microfiche (MF) or paper copy (HC) from the ERIC Document Reproduction Service, P.O. Box 190, Arlington, VA 22210. Orders should include ED number, specify format desired, and include payment for document and postage.

Further information on ordering documents and on current postage charges may be obtained from a recent issue of $R e$ sources in Education.

Planning Information Services in the Liberal Arts College Library. By Richard E. Miller and Bruce Morton. 1977. 27p. ED 154780 . MF-\$0.83; HC-\$2.06. 
A program and policy statement was developed by librarians at the Carleton College Library to address various planning demands being made of the library, to meet the specific and idiosyncratic information needs of the academic community, and to help clarify long-range goals of the library and policies by which these goals may be successfully pursued. The statement includes enumeration and discussion of the following: (1) specific factors that influence the quality and quantity of information services; (2) information needs that are seen as basic and recurring within the college community; (3) standards regarding the organization, development, and characteristics of the reference collection; (4) guidelines for reference facilities and environment; (5) personnel selection requirements and guidelines for professional development; and (6) evaluation procedures for the major elements of the information services program. A paradigm of the library planning process that graphically illustrates the complex relationships among the various parties to the planning process is included.

\section{The Relationship Between the Use of the} San Diego State University Library and Selected Personal Characteristics of the Student Population. By Mary Ada Burns. 1977. 74p. ED 154 807. MF-\$0.83; $\mathrm{HC}-\$ 3.50$.

This study examined the relationship between the use and nonuse of the Education Resource Center (ERC) at the San Diego State University Library and selected socioeconomic characteristics of graduate students enrolled in educational technology and librarianship classes. A questionnaire was administered to a sample population of 181 students; 140 were returned. While analysis of the data using the Statistical Program for the Social Sciences (SPSS) found relatively small differences between the personal characteristics of users and nonusers, two patterns based on other variants were indicated: library usage increased as students progressed through the university; and the average nonuser, while as intelligent or academically competent as the user, regarded the use of the library as strictly course-related. Frequency analysis distributions are summarized and tabulated for the following areas: service and reference materials; print materials; media software; function of the ERC; students' feelings toward the ERC; students' use and opinion of the university library and other libraries; and personal characteristics. Recommendations for further research include conducting another study that could better isolate the factors that contribute to use and nonuse of the ERC by students. The questionnaire and students' comments are appended.
A Study of Document Retrieval Times: An Example of How Data and Evaluation Can Lead to Improved Decision Making in Academic Libraries. By Cynthia A. Davenport. 1977. 20p. ED 154808. MF-\$0.83; HC-Not available from EDRS.

A document retrieval study conducted before and again after the building of a more centralized library at Syracuse University is used as an example of the kind of data gathering that can lead to improved decision making and evaluation of library services by library administrators. The study is discussed in detail to facilitate replication and to assist administrators in calculating the effect major changes or potential changes in library organization will have on the amount of time it takes to locate and retrieve materials. A specific application of the study would be to determine the extent to which a centralized library would be advantageous to a particular campus by measuring degrees of "cross over" and the impact changes in library organization would have on current library usage patterns, as well as the effects of changes in library organization on retrieval times, need for patron assistance, and management. Suggestions are offered for more effective data gathering and administrators are urged to use data to support their decisions.

Learning Resources Centers: Best of ERIC. A Selected, Annotated Bibliography. By Richard L. Ducote. ERIC Clearinghouse on Information Resources, Syracuse Univ., Syracuse, N.Y. 1977. 72p. ED 154 824. $\mathrm{MF}-\$ 0.83 ; \mathrm{HC}-\$ 3.50$.

This selected annotated bibliography lists almost 200 documents, added to the ERIC data base since 1972, which deal with adaptations of the learning resources center concept to specific situations. The bibliography is divided into ten sections: (1) elementary and secondary schools; (2) colleges and universities; (3) personnel and training; (4) resources in career education; (5) ethnic minorities; (6) environmental, health, and military resource centers; (7) combined public and school libraries; (8) budgeting; (9) production and equipment; and (10) facilities. A wide range of types of materials includes guidelines for planning, day-to-day operations, materials selection, evaluation, and administrative and technical processes.

Centralization of Current Periodicals in Elmer Ellis Library at the University of Missouri at Columbia. By June DuWeese and Michele Reiling. 1976. 19p. ED 153 605 . MF $-\$ 0.83 ; \mathrm{HC}-\$ 1.67$. 
The feasibility of centralizing current periodicals in this university library was investigated as a means of providing for greater accessibility to the periodicals, reducing theft, and improving the efficiency of technical services. Highlighted are concerns brought up by eight other academic libraries that have some type of centralized periodical collection: (1) the periodical room's being utilized as a study hall, (2) security, (3) circulation, (4) special control of high-risk titles, (5) periodical arrangement-by title or call number and (6) supervision of the periodical room. Appendixes include the questionnaire sent to the eight academic libraries, a layout of the periodicals room, and checkout and circulation procedures at the Ellis Library.

\section{Instructing the Community College Library} User: The Michigan Experience. By Han-

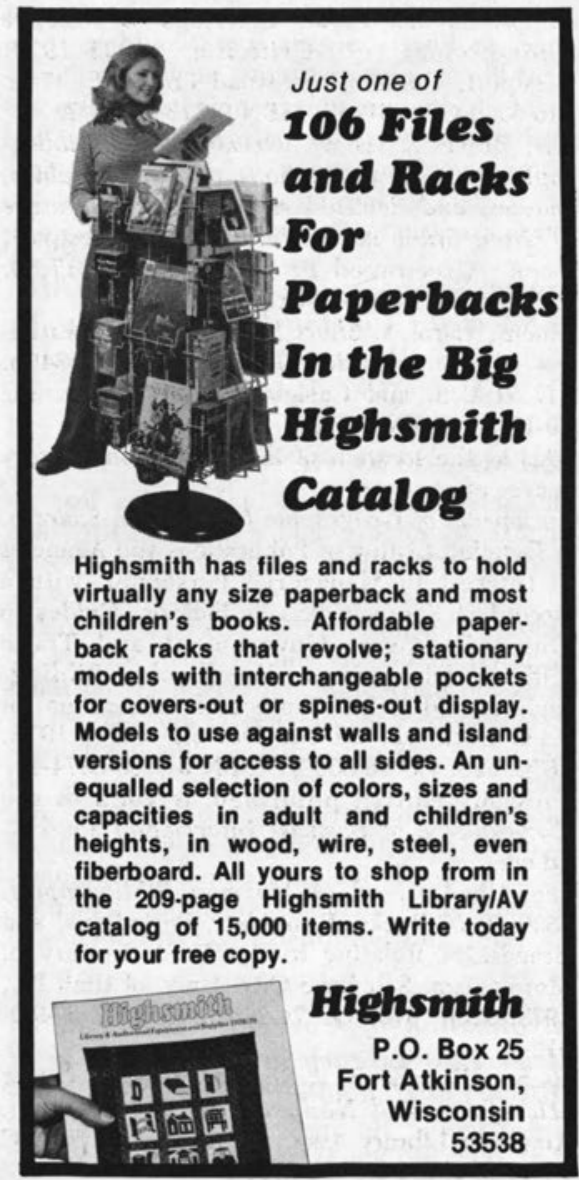

nelore B. Rader. 1977. 16p. ED 152331. MF-\$0.83; HC-\$1.67.

In addition to supporting instructional services, a major function of the community college library or learning resources center (LRC) is satisfying the widely differing information and communication needs of students enrolled in four basic types of programs: (1) preparatory courses for transfer to four-year institutions; (2) vocational-technical programs; (3) general education programs ending with an associate degree; and (4) continuing education programs. However, the LRC is often underutilized. Since one of the major reasons for this is the students' lack of library skills, library instruction programs should be designed to meet real information needs of students in specific courses. Librarians are advised to plan programs based on need-related objectives, develop closer faculty cooperation, and investigate the possibilities of obtaining program grants. The appendix provides a directory to thirty-two community college libraries in Michigan and describes their 1977 library instruction activities, ranging from none to comprehensive programs.

\section{Collection Development in 19 Libraries of} the Association of Research Libraries. By Wilmer H. Baatz. Washington, D.C.: Council on Library Resources, 1978. 90p. ED 153 606. MF-\$0.83; HC-\$4.67.

The objective of this study was to determine how large research libraries perform the function of collection development. The paper describes collection development theory within the formal organizational structure of the library, identifies the actual decision points involved in selection of materials, and examines the staff and facilities provided for collection development. Information was obtained through personal interviews of 300 librarians at eighteen ARL (Association of Research Libraries) libraries throughout the United States. Those interviewed included collection development officers, area and subject librarians, bibliographers, and curators. Findings are summarized in the following areas: allocation decisions, automation, approval plans and blanket orders, book funds, collection policies and committees, cooperation, elitism versus no one cares, evaluation of collections, exchanges and gifts, faculty versus librarians in selection, interlibrary loans, microforms, organization, preservation, reference, serials, space and staff, teaching, technical services involvement, use studies, and weeding and storage.

Guide to Chicano Resources in the University of Arizona Library. By Iliana Sonntag and others. Tucson: Univ. Library, 
Arizona Univ., 1976. 110p. ED 153663. $\mathrm{MF}-\$ 0.83 ; \mathrm{HC}-\$ 6.01$.

This guide is designed to call attention to and make more accessible the collection of materials in the University of Arizona Library on Mexican American history, culture, and social and economic development. It contains current materials, although some older works may be included due to their comprehensiveness. Each of the fifteen subject sections-general works, the arts, economics, education, folklore, health, history, labor and laboring classes, language, literature, politics and government, psychology, religion, sociology, and sports-is divided into: subject headings related to the specific topic; bibliographies; encyclopedias and dictionaries; indexes and abstracts for journal articles and books; directories of persons and organizations; a selected list of journals; and a list of pertinent University of Arizona theses. An index containing topics and phrases, as well as index terms, provides crossreferences to the subject sections of this guide.

\section{The Impact of Nonverbal Communications} on the Public Services Functions of Libraries. By Kay Weiss. 1976. 9p. ED 153 659 . $\mathrm{MF}-\$ 0.83 ; \mathrm{HC}-\$ 1.67$.

This annotated, selected bibliography of 21 monographs and articles on nonverbal communication is designed to help library personnel develop their perceptions of body language, thereby helping them respond more appropriately to user queries. Introductory material includes a brief literature review.

\section{OTHER PUBLICATIONS OF INTEREST TO ACADEMIC LIBRARIANS}

Alexander, Drury Blakeley. The Sources of Classicism. Five Centuries of Architectural Books from the Collections of the Humanities Research Center. Austin, Tex.: Humanities Research Center, 1978. 1v. unpaged. (Available from: The Humanities Research Center, the University of Texas at Austin, Postal Box 7219, Austin, TX 78712.)

Bowman, Mary Ann, comp. Western Mysticism: A Guide to the Basic Works. Chicago: American Library Assn., 1978. 113p. \$8. LC 7818311. ISBN 0-8389-0266-9.

Provides a selective, annotated bibliography to materials on the mysticism of Western culture. It includes the Eastern Orthodox and Jewish traditions.

Bruccoli, Matthew J. John O'Hara: A Descriptive Bibliography. Pittsburgh Series in Bibliogra- phy. Pittsburgh, Penn.: Univ. of Pittsburgh Pr., 1978. 324p. \$28.50. LC 77-15737. ISBN 0-8229-3349-7.

Building a Children's Literature Collection: A Suggested Basic Reference Collection for Academic Libraries and a Suggested Basic Collection of Children's Books. Rev. ed. by Harriet B. Quimby and Rosemary Weber. Choice Bibliographical Essay Series, no.5. Middletown, Conn.: Choice, 1978. 42p. \$4.75. LC 78-15886. ISBN 0-914492-04-7.

An updated edition of two bibliographical essays originally published in Choice in 1974 and 1975.

Canadian Library Association. Committee on the Directory of Interlibrary Loan Policies and Photocopying Services in Canadian Libraries. Directory of Interlibrary Loan Policies \& Photocopying Services in Canadian Libraries. Ottawa: Canadian Library Assn., 1978. 88p. $\$ 12$. ISBN 0-88802-119-4.

Caskey, Jefferson D., and Stapper, Melinda M., comps. Samuel Taylor Coleridge: A Selective Bibliography of Criticism, 1935-1977. Westport, Conn.: Greenwood Pr., 1978. 174p. \$16.50. LC 78-57765. ISBN 0-313-20564-7.

Davis, Bruce L., comp. Criminological Bibliographies: Uniform Citations to Bibliographies, Indexes, and Review Articles of the Literature of Crime Study in the United States. Westport, Conn.: Greenwood Pr., 1978. 182p. \$17.50. LC 78-59442. ISBN 0-313-20545-0.

Emmens, Carol A. Short Stories on Film. Littleton, Colo.: Libraries Unlimited, 1978. 345p. $\$ 17.50$ U.S. and Canada; $\$ 21$ elsewhere. LC 78-13488. ISBN 0-87287-146-0.

Aids in the location of the original short story source of a movie.

Encyclopedia of Geographic Information Sources. A Detailed Listing of Publications and Agencies of Interest to Managerial Personnel, with a Record of Sourcebooks, Periodicals, Guides to Doing Business, Government and Trade Offices, Directories, Handbooks, Bibliographies, and Other Sources of Information on Each Location. 3d ed. Detroit: Gale, 1978. 167p. \$28. LC 78-55032. ISBN 0-8103-0374-4.

Previous edition published as vol.2 of the Encyclopedia of Business Information Sources, $2 \mathrm{~d}$ ed.

Flake, Chad J., ed. A Mormon Bibliography, 1830-1930. Books, Pamphlets, Periodicals, and Broadsides Relating to the First Century of Mormonism. Salt Lake City: Univ. of Utah Pr., 1978. 825p. \$75. LC 74-22639. ISBN 0-87480016-1.

Fleischer, Eugene B. A Style Manual for Citing Microform and Nonprint Media. Chicago: American Library Assn., 1978. 66p. \$4.50. LC 78-9375. ISBN 0-8389-0268-5. 
Ford, George H., ed. Victorian Fiction: A Second Guide to Research. New York: Modern Language Assn. of America, 1978. 401p. \$17.50 cloth; \$9 paper. LC 77-083468. ISBN 0-87352254-0 cloth; ISBN 0-87352-254-9 paper.

Herbert, Theodore T., and Yost, Edward B. Management Education and Development: An Annotated Resource Book. Westport, Conn.: Greenwood Pr., 1978. 211p. \$17.50. LC 7791110. ISBN 0-313-20040-8.

Hill, Mary, and Cochran, Wendell. Into Print: A Practical Guide to Writing, Illustrating, and Publishing. Los Altos, Calif.: William Kaufmann, Inc., 1977. 175p. \$12 cloth; \$6.95 paper. LC 77-4083. ISBN 0-913232-43-2 cloth; ISBN 0-913232-44-0 paper. (Available from: William Kaufman, Inc., One First St., Los Altos, CA 94022.)

Jackson, Jane Clark. New American Pocket Medical Dictionary. New York: Churchill Livingstone, 1978. 380p. \$4.95. LC 78-3857. ISBN 0-443-08013-5.

Adaptation of Nancy Roper's Pocket Medical Dictionary.

Johnson, Lyndon Baines. The Johnson Presidential Press Conferences. New York: Earl M. Coleman Enterprises, Inc., 1978. 2v. \$60. LC 78-7992. ISBN 0-930576-02-0 v. 1; ISBN 0-930576-05-5 v.2.

Kruzas, Anthony T., ed. Encyclopedia of Information Systems and Services. A Guide to Information Storage and Retrieval Services, Data Base Producers and Publishers, Online Vendors, Computer Service Companies, Computerized Retrieval Systems, Micrographic Firms, Libraries, Government Agencies, Networks and Consortia, Information Centers, Data Banks, Clearinghouses, Research Centers, Associations, and Consultants. 3d ed. Associate editor, Linda Varekamp Sullivan. Detroit: Gale, 1978. 1,030p. \$95. LC 78-14575. ISBN 0-8103-0940-8.

Lowe, C. H. Notable Books on Chinese Studies. A Selected, Annotated, and Subject-divided Bibliographic Guide. Compiled and Edited, with Introductory Essays. Taipei, Taiwan: China Printing, Ltd., 1978. 228p. \$10. (Available from: C. H. Lowe, P.O. Box 652, Menlo Park, CA 94025.)

McKenna, Brian. Irish Literature, 1800-1875: A Guide to Information Sources. American Literature, English Literature, and World Literatures in English Information Guide Series, v.13. Detroit: Gale, 1978. 388p. \$22. LC 7411540. ISBN 0-8103-1250-6.

Maledicta: The International Journal of Verbal Aggression. Ed. by Reinhold Aman. Waukesha, Wis.: Maledicta Pr., 1977- .v.1 no.1$\$ 15 /$ invoiced; $\$ 10 /$ prepaid, U.S. and Canada; $\$ 12 /$ prepaid, elsewhere. (Available from:
Maledicta Press, 331 S. Greenfield Ave., Waukesha, WI 53186.)

Issued twice a year. "Specializes in collections and studies of swearwords, insults, curses, blasphemies, expletives, slurs, scatology, and other maledicta."

Martin, Michael, and Gelber, Leonard. Dictionary of American History. Rev. and enl. ed. Ed. by Leo Lieberman. Totowa, N.J.: Rowman and Littlefield, 1978. 714p. \$15. LC 78-14989. ISBN 0-8476-6104-0.

Previous edition published in 1966 under title: The New Dictionary of American History.

Meacham, Mary. Information Sources in Children's Literature: A Practical Reference Guide for Children's Librarians, Elementary School Teachers, and Students of Children's Literature. Contributions in Librarianship and Information Science, no.24. Westport, Conn.: Greenwood Pr., 1978. 256p. \$18.95. LC 77 91107. ISBN 0-313-20045-9.

Microform Market Place, 1978-1979: An International Directory of Micropublishing. Ed. by Jeanne Short. Westport, Conn.: Microform Review Inc., 1978. 229p. \$16.95. LC 74-4811. ISBN 0-913672-22-X.

Miller, Stuart Wayne. Library Use Instruction in Selected American Colleges. Univ. of Illinois Graduate School of Library Science Occasional Papers, no.134. Champaign, Ill.: Graduate School of Library Science, 1978. 47p. \$2.

A New Governance Structure for OCLC: Principles and Recommendations. Metuchen, N.J.: Scarecrow, 1978. 96p. \$8. LC 78-2099. ISBN 0-8108-1146-4.

A report prepared by Arthur D. Little, Inc.

Nitecki, Joseph Z., comp. and ed. Directory of Library Reprographic Services/A World Guide. 7th ed. Westport, Conn.: Microform Review Inc., 1978. 222p. \$12.95. LC 75-20413. ISBN 0-913672-20-3.

Occultism Update. An Inter-edition Supplement to Encyclopedia of Occultism \& Parapsychology. Ed. by Leslie Shepard. Detroit: Gale, 1978- no.1- \$30/4 issues. LC 7817299. ISBN 0-8103-0195-4.

Parker, J. Carlyle, comp. A Personal Name Index to Orton's "Records of California Men in the War of the Rebellion, 1861 to 1867." Gale Genealogy and Local History Series, v.5. Detroit: Gale, 1978. 153p. \$22. LC 78-15674. ISBN 0-8103-1402-9.

Public Library Information \& Referral Service. Ed. by Clara Stanton Jones. Syracuse, N.Y.: Gaylord Bros. Inc., 1978. 265p. \$12.50. LC 78-9703. ISBN 0-915-79406-3.

"Guide for libraries planning to introduce information and referral service, or for anyone interested in its philosophy and practice."

Reference and Subscription Books Reviews. 
1976-1977. Ed. by Helen K. Wright. Chicago: American Library Assn., 1978. 190p. \$11. LC 73-159565. ISBN 0-8389-3207-X.

Reprinted from Booklist, v.73 (Sept. 1976-July 15, 1977).

Robinson, Ruth E., comp. Buy Books Where-Sell Books Where: A Directory of Out of Print Booksellers and Their Specialties Including a Geographical Index. Morgantown, W.Va.: Ruth E. Robinson Books, 1978. 156p. \$17.50. (Available from: Ruth E. Robinson Books, Rt. 7, Box 162A, Morgantown, WV 26505.)

Rosser, A. J. Specification of User Requirements for an Automated Library Circulation System at the Western Australian Institute of Technology. Perth: Library, Western Australian Institute of Technology, 1978. 1v. unpaged. A\$70. (Available from: The Principal Librarian, T. L. Robertson Library, Western Australian Institute of Technology, Haymay Road, South Bentley, Western Australia 6102.)

Schaffer, Ronald. The United States in World War I: A Selected Bibliography. The War/ Peace Bibliography Series, no.7. Santa Barbara, Calif.: ABC-Clio Pr.; Oxford, Eng.: Clio Pr., 1978. 224p. \$21.50. LC 78-18456. ISBN 0-87436-274-1.

Schultz, Claire K. Thesaurus of Information Science Terminology. Rev. and expanded ed. Metuchen, N.J.: Scarecrow, 1978. 288p. \$9.50. LC 78-16878. ISBN 0-8108-1156-1.

Simmonds, Harvey; Silverstein, Louis H.; and Lassalle, Nancy, comps. Lincoln Kirstein: The Published Writings, 1922-1977; A First Bibliography. New Haven, Conn.: Yale Univ. Library, 1978. 157p. \$20. LC 78-58570. ISBN 0-87130-048-6. (Available from: The Eakins Press Foundation, 155 E. 42d St., New York, NY 10017.)

Smith, Robert Lewis, comp. and ed. Directory of Graduate Programs in Theatre Design and Technology. New York: United States Institute for Theatre Technology, Education Commission, 1978. 443p. \$8.50. (Available from: United States Institute for Theatre Technology, Inc., 1501 Broadway, New York, NY 10036.)

Stevens, Peter. Modern English-Canadian
Poetry: A Guide to Information Sources. American Literature, English Literature, and World Literatures in English Information Guide Series, v.15. Detroit: Gale, 1978. 216p. \$22. LC 73-16994. ISBN 0-8103-1244-1.

Stoddard, Richard. Theatre and Cinema Architecture: A Guide to Information Sources. Performing Arts Information Guide Series, v.5. Detroit: Gale, 1978. 368p. \$22. LC 78-14820. ISBN 0-8103-1426-6.

Vallentine, John F., ed. U.S.-Canadian Range Management, 1935-1977: A Selected Bibliography on Ranges, Pastures, Wildlife, Livestock, and Ranching. Phoenix, Ariz.: Oryx Pr., 1978. 337 p. $\$ 67.50$. LC 78-15627. ISBN 0-91270011-4.

Washington University. School of Medicine Library. Selection and Acquisitions Manual. St. Louis, Mo.: Washington Univ., 1978. 56p. $\$ 2.50$. (Available from: Washington Univ. Medical Center Library, St. Louis, MO 63110.)

Who Was Who in Journalism, 1925-1928. A Consolidation of All Material Appearing in the 1928 Edition of Who's Who in Journalism, with Unduplicated Biographical Entries from the 1925 Edition of Who's Who in Journalism. Gale Composite Biographical Dictionary Series, no.4. Detroit: Gale, 1978. 664p. \$42. ISBN 0-8103-0401-5.

Wilmeth, Don B. The American Stage to World War I: A Guide to Information Sources. Performing Arts Information Guide Series, v.4. Detroit: Gale, 1978. 269p. \$22. LC 78-53488. ISBN 0-8103-1392-8.

Wodehouse, Lawrence. British Architects, 1840-1976: A Guide to Information Sources. Art and Architecture Information Guide Series, v.8. Detroit: Gale, 1978. 353p. \$22. LC 7854116. ISBN 0-8103-1393-6.

Zoghby, Samir M., comp. Islam in Sub-Saharan Africa: A Partially Annotated Guide. Washington, D.C.: Library of Congress, 1978. 318p. $\$ 8.50$. LC 76-7050. ISBN 0-8444-0183-8. (Available from: Superintendent of Documents, U.S. Government Printing Office, Washington, DC 20402.) 


\section{Index to the Proceedings of the American Antiquarian Society 1812-1961}

\section{Compiled by Clifford K. Shipton}

"A superb index to a century and a half of publication by one of America's oldest learned societies .... Essential for all collections concerned with American history, and useful as a special reference tool even for those not holding the Proceedings."-Library Journal

This is the first comprehensive index to the Proceedings of the American Antiquarian Society. The articles and documents published in the Proceedings have always reflected the Society's broad historical activities and the strength of its superb library, which today houses the world's greatest collection of material printed through 1876 in what is now the United States. In the nineteenth century there was a strong archaeological and ethnological focus in the Proceedings related to the Society's interest in the antiquities of North, Central, and South America. In the twentieth the emphasis has been on the publication of bibliographies, primary sources, and other important basic tools for scholarship, as well as on other monographic literature. This index is a longawaited key to full access to the Proceedings.

Clothbound, vii, $603 \mathrm{pp}$. ISBN 0-912296-12-7. \$45.00.

distributed by:

\section{The University Press of Virginia}

\section{Box 2608 University Station}

Charlottesville, VA 22903

Enclosed is $\$$ for copy(ies) of Index to the Proceedings of the American Antiquarian Society.

Note: Academicians receive a $10 \%$ discount. Virginia residents must add $4 \%$ sales tax.

Name

Address

City, State, Zip 